SASKATCHEWAN NATURAL HISTORY SOCIETY

FINANCIAL STATEMENT - YEAR ENDING SEPTEMBER 30, 1967 INCOME

Memberships (including sales of Blue Jay)

Spec. Pub. \#1 - Guide to Sask. Mammals

Spec. Pub. \#2-Birds of the Sask. River

$\$ \quad 66.43$

$\$ 5,256.08$

Spec. Pub. \#3-Birds of Regina

105.93

59.05

14.00

Spec. Pub. \#5 - Birds of Lake

129.87

11.87

Publication-Birds of the Elbow

387.15

Sales of other merchandise

$\$ 4,033.17$

Less cost of sales

$2,743.42$

$1,289.75$

Donations (general)

$2,263.66$

Summer Meeting

Interest (bank account and bonds)

153.00

191.05

43.18

$\$ 4,327.79$

Miscellaneous (nominal rolls, etc.)

$\$ 9,583.87$

\title{
EXPENSE
}

Printing of Blue Jay (4 issues)

Printing and postage re: Newsletter

Honoraria

Postage

Office supplies and stationery (general)

Advertising and promotion

Bank charges less U.S. premium

Cost re: Maurice Street Sanctuary

Executive meetings; affiliation fees, etc.

Annual Meeting

$\$ 4,882.38$

487.81

600.00

344.16

269.00

272.97

42.16

31.00

62.69

4.25

$\$ 6,996.42$

$\$ 2,587.45$

EXCESS OF INCOME OVER EXPENSE

STATEMENT OF ASSETS AND LIABILITIES AS AT SEPTEMBER 30, 1967 ASSETS

Cash on hand

Cash in bank (current)

Cash in bank (savings)

Government of Canada bonds

Stock

Accounts receivable

Deposits with Posital Department

Publication subsidy and Contract re: Hours and the Birds

Less centennial grant

$\$ 9,040.00$

$5,000.00$

$\$ \quad 50.00$

$1,752.44$

$8,888.43$

300.00

726.41

73.45

45.00

$4,040.00$

$\$ 15,875.73$

LIABILITIES

University of Toronto Press (re: Hours and the Birds)

Less initial payment

$\$ 9,000.00$

$4,500.00$

$4,500.00$

150.00

$1,252.40$

130.66

240.00

$\$ 6,273.06$

Owing re: Honoraria

\section{NET WORTH}

Balance as at September 30,1966

Increase for year ending September 30, 1967
$\$ 7,015.22$

$2,587.45$ 


\section{THE SASKATCHEWAN NATURAL HISTORY SOCIETY}

\section{OFFICERS (October, 1967 to October, 1968)}

Honorary President.

President

Past President.

First Vice-President

Second Vice-President.

Treasurer

Corresponding Secretary... Margaret Belcher, 2601 Winnipeg Street, Regina

Recording Secretary.. Maureen Rever, University of Sask., Saskatoon

\section{DIRECTORS}

One-year directors: Ross Homer, Prince Albert; Mrs. Cy Knight, Moose Jaw; Frank Roy, Saskatoon; Hugh Smith, Regina; Frank Switzer, Yorkton.

Two-year directors: Mrs. Lillian McBean, Swift Current; M. Timothy Myres, Calgary, Alberta; Robert W. Nero, Winnipeg, Manitoba; Mrs. D. Sutton, Rocanville; Steve Waycheshen, Kelvington.

Three-year directors: J. D. Hayward, Wolseley; Bryan Isinger, Yellow Creek; Ernie Kuyt, Fort Smith, N.W.T.; E. B. Peterson, Calgary; Mrs. K. H. Skinner, Indian Head.

\section{PRESIDENTS OF LOCAL NATURAL HISTORY SOCIETIES}

Gordon Silversides, 1201 Grace St., Moose Jaw; Dr. G. B. Howard, 47 21st St. E., Prince Albert; Jack MacKenzie, 6 - 38 Spence Street, Regina; M. Ross Lein, 918 - 10th St., Saskatoon; Dr. Jan Looman, Experimental Station, Swift Current; Larry Morgotch, 15A Bradbrooke Apts., Yorkton.

\section{CHAIRMEN OF COMMITTEES}

Bookshop Review Committee: James Jowsey, 3433 21st Street, Regina; Crest Committee: Ruth Chandler, Shaunavon; Distribution, Mrs. Joyce Smith, 1357 Minto, Regina; Local Societies: William Brownlee, 3628 Mason Ave., Regina; Membership: Frank Brazier, Box 1121, Regina; Newsletter: James Slimmon, 2526 Hanover Ave., Saskatoon; Prairie Dogs: David Chandler and Ruth Chandler, Shaunavon; Prairie Nest Records Scheme: Robert W. Nero, Manitoba Museum of Man and Nature, Winnipeg 2; Publications: C. Stuart Houston, 863 University Drive, Saskatoon; Publicity: M. Ross Lein, 918 - 10th St., Saskatoon; Research Awards: Elmer Fox, 3455 Rae Street, Regina.

THE BLUE JAY

Editor: George F. Ledingham; Assistant Editors: Margaret Belcher, Robert W. Nero; Junior Naturalists' Editor: Mrs. Joyce Deutscher.

All items for publication should be submitted to George F. Ledingham, Editor, 2335 Athol Street, Regina.

\section{MEMBERSHIPS}

The classes of memberships in the Saskatchewan Natural History Society are as follows: Regular, $\$ 2.00$; Supporting, $\$ 3.00$; Sustaining, $\$ 5.00$; Junior (including schools), $\$ 1.00$. The Blue Jay and Newsletter are sent without charge to all members not in arrears for dues.

Send all renewals and new memberships to Frank Brazier, Treasurer, SNHS, Box 1121, Regina, Sask.

\section{REPRINTS}

Requests for quantities of reprints of any article printed in the Blue Jay should be sent to Printcraft Ltd., Regina, Sask., within one month of publication. Contributors wishing a few extra copies of the current Blue Jay may get them at cost. Requests for these should be made to the Editor when material is submitted for publication. 